\title{
The Holy Spirit and the Ongoing Formation of Presbyters
}

\author{
DARIUSZ LIPIEC
}

The John Paul II Catholic University of Lublin, Poland

dlipiec@kul.pl, ORCID: 0000-0002-8890-2062

\begin{abstract}
The Holy Spirit plays a significant role in the process of the ongoing formation of priests. His activity can be perceived in three aspects. (1) He strengthens the charism given during the ordination to the priesthood in such a way that the presbyter is in constant connection with the Father and with the Son. (2) The Third Person of the Holy Trinity raises anew the pastoral love which is necessary for fulfilling the mission of priesthood and which leads to (3) the deepening of the bond between the priest and God. This enhances the priest's pursuit of his own holiness. The priest should actively respond to the Holy Spirit, Who initiates the contact by his engagement, and he should cooperate with Him for the sake of the salvation of the faithful, in order to build God's Kingdom on earth.
\end{abstract}

Keywords: Holy Spirit, the ongoing formation of presbyters, the permanent formation of presbyters, formation of priests, priestly formation

The ongoing formation of presbyters is the continuation of the seminary formation which prepares future priests for ordination. Its aim "must be that of promoting a general and integral process of constant growth, deepening each of the aspects of formation human, spiritual, intellectual and pastoral - as well as ensuring their active and harmonious integration, based on pastoral charity and in reference to it" $(P D V, 71)$. The process of priestly formation, which consists of the seminar formation and of the ongoing formation, is perceived as uniform and integral for the personal development and sanctification of the presbyter and for his pastoral ministry. The ongoing formation is kindled by two sources: the supernatural, which is connected with the implementation of the gift of priesthood given by God and which requires constant submission to God's will; and the natural, which is the result of the pastoral conditions and of the contemporary challenges in the world, where the presbyters minister. The ongoing formation is based on the pastoral charity of Christ, which constitutes its internal rule, its starting point and reference, and which is given to the presbyter as a gift and as a task.

The pastoral charity of a presbyter implies the permanent nature of the ongoing formation. It concerns all presbyters, regardless of their age, life conditions and the nature of their ministry. Presbyters are personally responsible for their own formation throughout their whole lives, although they can use the help of others, especially 
of the bishop and of other presbyters, as they belong to the presbyterate. The bishop and people appointed by him indicate the forms and means which can contribute to the development of the personality, sanctification and the effectiveness of the priest's ministry (see OT, 22).

\section{The Holy Spirit Who "Stirs into Flame the Gift of God"}

The term "to stir into flame the gift of God" in reference to the ongoing formation of presbyters was introduced into theology by John Paul II. In the apostolic exhortation Pastores dabo vobis he quotes the Second Letter of Saint Paul to Timothy, in which the apostle reminds his student "to stir into flame the gift of God" that he has in him (PDV, 70; see $2 \mathrm{Tm} \mathrm{1,6).} \mathrm{The} \mathrm{Pope} \mathrm{relates} \mathrm{this} \mathrm{part} \mathrm{of} \mathrm{the} \mathrm{letter} \mathrm{to} \mathrm{priesthood} \mathrm{which}$ is the charism given to the Church by the Holy Spirit for Her ministry. Priests, similarly to Timothy, receive this gift in the sacrament of ordination. The gift is, at the same time, the task for the ordained. The priest who received it, was invited by God to co-operate with Him, which results in the development of the received charism. Saint John Paul II indicates that the development is a kind of a moral obligation - the man is not allowed, as it is pointless and it contradicts the unity with God, to cease developing this gift $(P D V, 70)$. Renunciation of the development of the charism reflects disloyalty to the Holy Spirit and denial of the given mission. Giving consent to God's will is not a single act, although it begins by the single act of the will which is then being confirmed time and again. Giving the consent to God is an ongoing process because the priest's vocation is the calling for lifetime. Development of the gift of priesthood, received in the liturgy of ordination, is of the utmost importance and it constitutes the theological basis for the ongoing formation of presbyters. ${ }^{1}$

The term "stirring" into flame the gift of the Holy Spirit also refers to the ontological and spiritual condition of the presbyter. According to Saint John Paul II, the charism of priesthood resembles a flame burning in the man. The term "stirring into the flame" indicates the way it lives in the presbyter. This charism can be developed in a stronger or a weaker way, it may or may not be constantly developed in the process of the ongoing formation, resulting in the progress in the spiritual life and in the ministry of a priest (see $P D V, 70$ ). Unfortunately, it is also possible to neglect the charism and to seriously limit its fruits. It depends on the personal engagement of the presbyter. Therefore, the Pope, following Saint Paul, indicates the necessity to constantly "rekindle" the charism with the conscious and systematic engagement into its development (PDV, 70). Even a short pause in the development, not only neglecting it, results in the "destruction" of the charism. Therefore, "rekindling" of

1 The Polish Episcopal Conference, List, no. 1. 
the charism is necessary to remain faithful to Christ Who is calling, as well as for the enlivening of the presbyter in order to make him "a new creation" and to renew his ministry. ${ }^{2}$

The cooperation between the presbyter and the active Holy Spirit constitutes the essence of the ongoing formation. Although the presbyter is responsible for undertaking and implementation of the formation, it is the Holy Spirit Who commissions the task. He, as the source of the gift, is also the Giver of its development and growth. God Himself provides the dynamics of the grace, which is inseparable from the gift of vocation. God is the Giver Who supports the presbyter with His grace on his way of undertaking various tasks and challenges imposed on him (see GeE, 23).

God, the Giver of vocation, is also the Giver of grace which is necessary for the implementation of the gift $(P D V, 24-25)$. The presbyter who is the manager of his own formation is, first and foremost, called to be open to the cooperation with the Holy Spirit in this task. Being open to this cooperation mainly means being ready to accept God's initiative and the diversity of His actions. It is strictly connected with the obedience to the Holy Spirit because the gift of priesthood as well as the presbyter's ongoing formation must not be based on one's imagination or aspirations but solely on God Himself. In order to make a good use of God's gift, it is necessary for the presbyter to be open to the spiritual direction of the Holy Spirit, to His visions of priesthood and of the ongoing formation.

Each presbyter must consequently and constantly implement God's plan for the ongoing formation in his unconditional submission to the Holy Spirit. Only then it is possible to make a good use of God's gift and to direct one's formation, which aims at the development of the presbyter, to make him in the likeness of Jesus Christ the Good Shepherd. Any obstacles in the cooperation with the grace from the Holy Spirit can result in disrupting God's gift of vocation and the plan, which He imposed on the presbyter, bestowing him with the holy ordination.

Being open to the grace from the Holy Spirit Who is leading the presbyter on the way of his ongoing formation, appeals for his deepest reflection. It is not only an intellectual effort, but it also requires profound prayer and contemplation (see $\mathrm{DeV}, 65$ ). These factors enhance the recognition of God's will and they encourage the human to obey Him. Intelligence helps to recognize the deepest meaning of God's plan and to draw proper conclusions which enable to use it in the life and in the priestly formation.

2 Congregation for the Clergy, Directory, no. 69. 


\section{The Holy Spirit Who Infuses the Pastoral Charity}

One of the aims of the ongoing formation of presbyters is to maintain them in their fidelity to their ordination. This ministry is based on the pastoral charity which is also "the soul and the inner shape" of the ongoing formation of presbyters. "The Holy Spirit, who infuses pastoral charity, introduces and accompanies the priest to an ever deeper knowledge of the mystery of Christ, which is unfathomable in its richness (cf. Eph. 3;14ff.) and, in turn, to a knowledge of the mystery of Christian priesthood" $(P D V, 70)$. Pastoral charity of presbyters is rooted in the pastoral charity of Christ the Good Shepherd, Who loves His sheep and Who leads them to unity with His Father ${ }^{3}$.

Pastoral charity of presbyters is to serve for the welfare of the Church - the mystery, community and mission. In the Church- the mystery, the ongoing formation is presented as a process which leads the priests, guided by the Holy Spirit, to become the people of profound faith and its witnesses. The Holy Spirit leads presbyters to the deepest awareness of their relationship with Christ Who appointed them, in order to make them better and better ministers of God's mysteries. This means leading towards the deeper awareness of their identity which results from being rooted in Christ and in the Church-the mystery ${ }^{4}$.

Leading the presbyter to become more of a man of faith results in the constant being with God in such a way "that he grow[s] in understanding of who he truly is, seeing things with the eyes of Christ. The priest must safeguard this truth with grateful and joyful love" $(P D V, 73)$. It requires being open and constant resorting to the Holy Spirit in order to deepen their faith and to make the presbyter an efficient tool of God's grace. It also requires the attitude of submission to become the more devoted servant of Christ in the Church.

Holy Spirit leads presbyters to the deeper awareness of being shepherds of God's people (see $P O, 1)$. It deepens their awareness of being in the community of those called for salvation and strengthening the relationships with their presbyterate. The priest was called in the community, among others who were called. He should not feel cast aside but he must be integrated with the group of other believers. The awareness of that promotes the development of brotherly love in presbyters, which is the inspiration from the Holy Spirit. The Holy Spirit is also present in the bonds between the presbyter and his brothers in faith, thanks to that he can develop and deepen these bonds. The assistance of the Third Person of the Holy Trinity helps the presbyter to raise the awareness of being a part of the ecclesial community and to develop the bonds with other members of the Church, with priests as well as with laymen, especially in his own parish community 5 .

\footnotetext{
See Goyret, Powołani, 95-100.

See Dyrek, "Powrót do pierwotnej miłości," 92-94.

Congregation for the Clergy, The Priest, no. 5.
} 
The ongoing formation helps presbyters to be open to the acting of the Holy Spirit, Who bestows the members of the community with various gifts and charisms in order to help them build the ecclesial community. The assistance of the Third Person of the Holy Trinity makes presbyters help the bestowed to discover the gifts and to explain the meaning of them to the community. Led by the Holy Spirit, presbyters support other members of God's people in showing their obedience to the Holy Spirit and submission to His guidance (see GeE, 96)

Submission to the guidance of the Holy Spirit helps presbyters to deepen their bonds with the bishop and with other members of the diocesan presbyterate (see $P O, 2$ ). The ongoing formation takes place in the presbyterate and for the presbyterate. The Holy Spirit induces presbyters to build closer unity between their brothers in priesthood, which results in the deeper involvement into the life of the presbyterate of their own diocese, rekindles the feeling of responsibility for the future of the local Church and awakens brotherly love and solidarity with other priests. Submission to the guidance of the Third Person of the Holy Trinity enables presbyters to increase the efforts in the task of building sacramental community as well as in rekindling the spirit of sacrifice in their pastoral ministry.

Diocesan presbyterate, based on the sacrament of ordination, is also built on the natural level. Although the bonds between the clergy do not result from the natural affinity, but from the supernatural one, they are helpful in developing such features as: solidarity, brotherly love, kindness, friendship, empathy and other similar ones'.

Opening to the Holy Spirit and submission to His guidance enable presbyters to be open to their ordained brothers who need particular support and help. It concerns the priests who need both: spiritual and material help. The Holy Spirit bestows presbyters with particular sensitivity, not only with reference to the cooperation with those who are faithful in their ministry but also to the needs of those who are weakened on their way. The assistance of the Third Divine Person helps the presbyter to overcome the temptation to swagger - they are guided to adopt the attitude of humbleness - just like Christ Who washed the feet of His disciples.

Submission to the guidance of the Holy Spirit in the process of the ongoing formation constantly reminds presbyters of the mission and calls for their readiness to implement the formation in the current conditions. The grace from the Holy Spirit allows for the deeper understanding of the essence of the priest's mission and its importance for people whom the presbyters are to serve. The ongoing development of priests reminds them of the importance of the Church's mission in their lives and of their own pastoral vocation in the Church.

The guidance of the Holy Spirit confirms the presbyters' awareness of what is important in their ministry and helps them to remain faithful in their vocation. It is very important because of the external obstacles on the presbyters' way of the pas-

6 See Steczek, "Wspólnota kapłańska," 107-114. 
toral ministry and their human imperfections (see $\mathrm{DeV}, 59$ ). Devoting oneself and one's ministry to the Holy Spirit in the process of the ongoing formation is not only an act of recognition of one's own weakness in the light of contemporary challenges, but it also creates a permanent bond with the Holy Spirit. It also means a permanent consent to be guided and directed by the Holy Spirit in the presbyter's ministry. The Holy Spirit sustains the man in his weakness and indicates the best direction and proper means for the realization of the given mission.

\section{The Holy Spirit Who Strengthens the Bonds with God}

Remaining faithful to Jesus Christ the Good Shepherd is an important aim of the ongoing formation of presbyters. "It is the Holy Spirit, poured out in the sacrament, who sustains the priest in this faithfulness and accompanies him and encourages him along this path of unending conversion" (PDV, 70). The Holy Spirit is a very important agent in the process of deepening pastoral charity and in taking responsibility for the Church and for Her mission, in the deepening of the bond between the presbyter and God and in the process leading to personal sanctification. He is not only the originator of the process - He is constantly present in its realization?

The activity of the Holy Spirit in the process of the permanent conversion does not release the priests from their own responsibility. "It is the Holy Spirit, poured out in the sacrament, who sustains the priest in this faithfulness and accompanies him and encourages him along this path of unending conversion. The gift of the Spirit does not take away the freedom of the priest. It calls on the priest to make use of his freedom in order to cooperate responsibly and accept permanent formation as a task entrusted to him. Thus permanent formation is a requirement of the priest's own faithfulness to his ministry, to his very being" (PDV, 70).

In the process of the permanent conversion of a presbyter and his configuring to the likeness of Jesus Christ, the spiritual dimension of the formation is of particular importance. "The Spirit, by consecrating the priest and configuring him to Jesus Christ, head and shepherd, creates a bond which, located in the priest's very being, demands to be assimilated and lived out in a personal, free and conscious way through an ever richer communion of life and love and an ever broader and more radical sharing in the feelings and attitudes of Jesus Christ" (PDV, 72).

The spiritual formation of a presbyter is connected with the pursuit to deepen his personal bond with Christ, with conducting a dialogue with God, with great trust to Him and with the profound experience of the presence and acting of the Holy Spirit (see $P O, 22$ ). Deepening the bond with God results in increasing the effectiveness of

7 See Galis, Permanentná formaciá, 160-164. 
the means that the presbyter uses in this process. Experiencing the presence of the Holy Spirit leads to a better understanding of God's Revelation and to more effective using of It in one's life and ministry. Enlightening the presbyter's mind, the Holy Spirit lets him deeply penetrate the mystery of God's life (see VD, 15-16). He introduces the Word of God to fully equip the life of a priest who gradually applies It to his life conditions, seeks for the answers to his questions and to the questions of the faithful who were entrusted to him ${ }^{8}$. The Holy Spirit encourages the presbyter for submission to God Who addresses him personally in order for the presbyter to realize His indications in his own life. It is particularly important in difficult situations which require the man's self-denial.

Experiencing the Holy Spirit and submission to His guidance is also important for the personal meeting with Christ in sacraments. In order to continue the process of permanent conversion it is necessary to meet the merciful Saviour Who supports the man in his development in the sacrament of penance and reconciliation. What is more, it is necessary to be in the constant unity with Him in the sacrament of Eucharist (see $\mathrm{DeV}, 63$ ). Eucharist is the means for sanctifying the presbyter when It is celebrated to be united with Christ present in the form of bread and wine, but also when the presbyter worships His presence in the Holy Sacrament (see SC, 12-13). Ministering other sacraments, which mainly aim at sanctifying the faithful, should also, under the influence of the Holy Spirit, lead to the sanctification of the minister and to strengthening his bond with Christ ${ }^{9}$.

The Holy Spirit is the teacher of the prayer and He contributes to its effectiveness. He leads the presbyter to fidelity in celebrating the Liturgy of Hours and to practising personal prayer in various forms, such as: meditation, rosary prayer, as well as other prayers which help to develop his personal piety. Personal prayer, celebrated under the guidance of the Holy Spirit, leads to the personal meeting with God, to the dialogue and union with Him (see $V D, 80$ ).

The ongoing formation of presbyters, meant as a way of the permanent conversion under the guidance of the Holy Spirit, leads to preventing difficult situations in their lives, and, in case such situations take place, helps them overcome the problems ${ }^{10}$. Experiencing one's weakness enables them for self -improvement, and, when they entrust themselves to the Third Person of the Holy Trinity, for the greater trust into God's mercy. The risk of occupational burnout and becoming merely a religious functionary is a call for deepening the bond with the community, firstly with the priestly community, and next with the community of the lay faithful (see $E G, 178$ ). Realization of the ongoing formation under the guidance of the Holy Spirit makes it possible to resist the temptation to reach for power and material wealth and to work

See Siwek, "Głosiciel słowa Bożego," 67-74.

See Rogowski, "Eucharystia w życiu kapłana," 75-82.

10 Congregation for the Clergy, Ratio, no. 84. 
on the attitude of service for those entrusted to them. Submission to the guidance of the Third Person of the Holy Trinity strengthens in celibacy and in the development of the attitude of the total submission to $\mathrm{God}^{11}$.

\section{Conclusion}

The Holy Spirit is constantly present in the priestly formation. He accompanies those who are preparing for the sacrament of the holy ordination and gives support to presbyters in their priestly life and ministry. The assistance of the Third Divine Person begins at the moment of calling the man. God's acting is anticipatory of the spiritual effort and of the pastoral effort of the priest. The Holy Spirit supports the presbyters' ministry in order for them to fulfil their vocation in a faithful way, to the likeness of Jesus Christ the Good Shepherd. He also supports the development of their personal bonds with God, and, as a consequence, their personal development and pursuit for sanctification. The initiative of the Holy Spirit Who constantly accompanies presbyters and invites them for cooperation, requires a conscious, free-will and active response of the called. Cooperation with God's grace makes it possible to fulfil the priestly vocation and mission.

\section{Bibliography}

Augustyn, J., Kapłańskie ojcostwo (Kraków: WAM 2013).

Benedict XVI, Post-Synodal Apostolic Exhortation "Sacramentum caritatis" (2007) (= SC).

Benedict XVI, Post-Synodal Apostolic Exhortation "Verbum domini” (2010) (=VD).

Cencini, A., Dziewictwo i celibat dzisiaj. W kierunku seksualności paschalnej (Kraków: Salwator 2005).

Dyrek, K., "Powrót do pierwotnej miłości," Pasterz według Serca Jezusa (ed. J. Augustyn K. Dyrek) (Warszawa: Wydawnictwo Księży Marianów 1996) 81-100.

Francis, Post-Synodal Apostolic Exhortation "Evangeii gaudium” (2013) (=EG).

Francis, Post-Synodal Apostolic Exhortation "Gaudete et exsultate” (2018) (= GeE).

Galis, T., Permanentná formaciá kňazow vo svetle "Pastores dabo vobis" (Badlin: Kňazsky seminar sv. Františka Xaverského 1998).

Goyret, P., Powołani, konsekrowani, posłani. Sakrament kapłaństwa (Warszawa: Wydawnictwo Księży Marianów 2004).

John Paul II, Encyclical “Dominum et Vivificantem” (1986) (= DeV).

John Paul II, Post-Synodal Apostolic Exhortation "Pastores dabo vobis" (1996) (= PDV).

11 See Cencini, Dziewictwo i celibat dzisiaj, 166-181. 
The Conference of the Polish Episcopal Council, List do prezbiterów Kościoła w Polsce "Abyśmy nie ustali $w$ drodze" (8.03.2006), www.episkopat.pl/abysmy-nie-ustali-w-drodze [accessed on 29.01.2020].

Congregation for the Clergy, Directory on the Ministry and Life of Priests (1994).

Congregation for the Clergy, The Priest, Pastor and Leader of the Parish Community. Instruction (2002).

Congregation for the Clergy, Ratio Fundamentalis Institutionis Sacerdotalis. The Gift of the Priestly Vocation (2016).

Rogowski, R., "Eucharystia w życiu kapłana,” Sztuka bycia księdzem. Poradnik (ed. J. Augustyn) (Karków: WAM 2011) 75-82.

Selejdak, R., Stawać się kapłanem trzeciego tysiąclecia (Częstochowa: Kuria Metropolitalna, Tygodnik Katolicki "Niedziela" 2001).

Siwek, G., "Głosiciel słowa Bożego," Sztuka bycia księdzem. Poradnik (ed. J. Augustyn) (Karków: WAM 2011) 67-74.

Stachowiak, D., Dialog w formacji kapłańskiej (Kraków: Homo Dei 2013).

Steczek, B., "Wspólnota kapłańska," Sztuka bycia księdzem. Poradnik (ed. J. Augustyn) (Karków: WAM 2011) 107-114.

The Second Vatican Council, Optatam totus. The Decree on Priestly Training (1965) (= OT).

The Second Vatican Council, Presbiterorum Ordinis. The Decree on the Ministry and Life of Priests (1965) (=PO). 
